\title{
Reflections on a methodology for analyzing professional practice and its possible use in nursing
}

\author{
Reflexões sobre um dispositivo de análise da prática profissional \\ e sua possível utilização na enfermagem \\ Reflexiones acerca de un dispositivo de análisis de la práctica \\ profesional y su posible utilización en la enfermería
}

How to cite this article:

Spagnol CA, Lorence B, Dufournet-Coestier V, Silva AA. Reflections on a methodology for analyzing professional practice and its possible use in nursing Rev Esc Enferm USP. 2019;53:e03434. DOI: http://dx.doi.org/10.1590/S1980-220X2018004803434

\author{
Carla Aparecida Spagnol ${ }^{1}$ \\ Béatrice Lorence ${ }^{2}$ \\ Virginie Dufournet-Coestier ${ }^{3}$ \\ Amanda Alemar Silva ${ }^{1}$ \\ ${ }^{1}$ Universidade Federal de Minas Gerais, Escola \\ de Enfermagem, Belo Horizonte, MG, Brazil. \\ ${ }^{2}$ Université de Cergy-Pontoise, Ecole Supérieure \\ du Professorat et de l'Education, Site de \\ Saint-Germain-en-Laye, Versailles, France. \\ ${ }^{3}$ Université de Cergy-Pontoise, \\ Laboratoire EMA, Versailles, France.
}

\begin{abstract}
In order for nursing work not to become mechanistic, the team needs to develop a critical eye to its knowledge, its know-how and its know-to-be. The training of nursing professionals from a critical and reflective perspective motivated this study, which was based on the theoretical reference and the experience of the authors with use of the analytical methodology of the Groupe Entrainement de Analyze de Situations Éducatives (Training Group to Analyze Educational Situations) professional practice. This methodology aims to analyze professional situations in a group with the presence of a facilitator. The objective is to analyze the contributions of the Groupe Entrainement de Analyze de Situations Éducatives to train reflective professionals in nursing. The steps, rules of operation and the role of the participants are explained in order to promote a safe environment for all, enabling group members to develop hypotheses to understand the situation and develop analysis and reflection skills. It is concluded that this methodology offers the opportunity to open a space for reflective thinking, respecting the different roles and times intended for the speech of each participant, building their professional identity.
\end{abstract}

\section{DESCRIPTORS}

Nursing; Education, Nursing; Education, Nursing, Continuing; Professional Practice. 


\section{INTRODUCTION}

Nursing care is not limited to the use of equipment, materials and structured knowledge, but it is also limited to a process of relationships, interventions and subjectivities. However, despite advances in health work organization, nursing care is still focused on the technical-scientific procedures and the tasks to be performed, which leads to a fragmented and technical professional practice, characterizing mechanized work and impersonality in the organizational relationships ${ }^{(1)}$.

It can be said that this is an inheritance of the Taylorist principles adopted in the organization of nursing work, in which nurses' performance is still based on supervision and task control most of the time, which hinders the development of teamwork from a more critical and reflective professional practice ${ }^{(2)}$.

However, nursing is a profession that has its own field of knowledge, foundations and practices, which require professionals to have technical competence, capacity for reflection, critical analysis and constant acquisition of scientific knowledge. In order for the work to not become mechanistic and inhumane, the nursing team must find strategies to solve problems, face the challenges, recognize their limits and develop a critical eye to their knowledge, their know-how and their know-to-be.

Training nursing professionals from a critical and reflective perspective motivated this theoretical reflection, which began during the post-doctorate studies in Educational Sciences conducted by the first author at Cergy-Pontoise University, France. During this period, it was possible to follow the work of two facilitators who use a professional practice analysis (PPA) methodology called the Training Group to Analyze Educational Situations (Groupe Entraînement de Analyse de Situations Éducatives - GEASE) ${ }^{(3-4)}$ in training professionals in the area of education and in the medical-social sector. This methodology is also used in nursing courses and in continuing education in health services in France ${ }^{(5)}$.

The expression "analysis of practices" is related to a number of methods that have begun to become increasingly important since 1990 in the initial training or continuing education of professions in the areas of education and the social sector. These methods were initially used in the University Institutes for Teacher Training in France. Most of these devices bring together groups of workers who come from different establishments but who conduct the same profession to collectively analyze their practice, so that they are often used in professions that have interpersonal relations as their object of work ${ }^{(6-7)}$.

In this perspective, the analysis of practices presents itself as an interesting training modality when an important part of the work cannot be prescribed, meaning when the professional needs to permanently construct responses adapted to different singular situations that arise in the work. This analysis is also identified as a means of professionalization, insofar as it enables working the identity dimension in the construction of a profession ${ }^{(7)}$.

Professional practices in the health area are dynamic and influenced by the changes that occur in contemporary society. In addition, nursing and other professions in the area primarily work on interpersonal relationships, mainly with the subjective dimension of professionals and users. Faced with these and other factors, teams need to constantly reflect on their practice, since there are no ready answers to the various situations encountered in everyday life.

In view of this fact, when the author had learned the PPA as a methodology of critical and reflexive training and upon returning from her postdoctoral studies she then elaborated the extension project: "Use of a method to analyze professional practice in continuing education to train reflective professionals in nursing." This project also included the participation of a scholarship student, an undergraduate nursing student of the Nursing School of the Universidade Federal de Minas Gerais.

Based on these experiences and the theoretical contribution that supports this training methodology, the authors raised the question: what are the contributions of using PPA method in constructing a reflexive professional position in Brazilian nursing? How should we think about the transpositions, specifically, of the GEASE method for training nursing professionals in Brazil?

The authors have developed this theoretical study in order to answer these questions and clarify theoretical subsidies for training and continuing education of nursing professionals and projects (teaching, research and extension) in the health area, which can contribute to advancing and developing knowledge in the profession. This can further enhance and consolidate sharing knowledge and practices through national and international exchanges.

It is worth noting that in Brazil only one investigation was found which uses a method to analyze practice adapted to GEASE as a data collection instrument, which was in a survey carried out with nursing workers in public health care in the city of Campinas-SP ${ }^{(8)}$. Thus, the scarcity of literature on the subject also constitutes justification for performing this theoretical article.

Therefore, the objective of this theoretical reflection is to analyze the contributions of the GEASE method for training reflexive professionals in nursing.

\section{ANALYSIS OF PROFESSIONAL PRACTICE: CONCEPTS AND BRIEF HISTORY}

In this study, the word practice is not related to a work about the techniques and procedures performed by professionals, but it is used in the sense of praxis, understood as the complex and inseparable relationship of thinking and doing, considering that workers build their practice in everyday experience, in the events that occur, in the way in which they treat them and in the routines which are $\operatorname{set}^{(9)}$.

From the understanding of the word practice, it is sought to understand the theoretical approaches that gave origin to the analysis of practices and to approach some concepts that support its various methods. In a synthetic way, it can be said that the analysis of the practices developed presently has its origin in two main theoretical lines: the works of Balint and the reflexive approach of $\operatorname{Schön}{ }^{(7-8,10)}$. 
In the 1940s at the Tavistock Clinic in London, a physician and psychoanalyst named Michaël Balint found that traditional medical training did not prepare a physician to relate to their patients. On the other hand, he hypothesized that the relationship between the patient and their physician (such as trust, dependence, safety) was of crucial importance in the healing process. Thus, he proposed seminars to general practitioners, now known as "Balint groups", where they could reflect on the doctor-patient relationship from real situations, having the psychoanalysis as theoretical reference and coordinated by psychoanalytical leaders. This was an interesting approach to understand what was happening in this relationship, in the emotional aspect, and which worked with the concepts of transference, countertransference and unconsciousness as the main theoretical tools ${ }^{(11-13)}$.

In France, practice analysis methods were initially used in education, and it was found that the Balint model was widely diffused in this area, becoming a relevant reference in the work carried out with groups of teachers, since the teacherstudent relationship also mobilizes affections, emotions and representations, as in the case of the relationship that occurs between doctors and their patients. These methods had the purpose of helping the teacher to clarify the repetition of certain behaviors, their intuitive reactions, their bad moods in front of some students (like feeling beaten, for example) ${ }^{(7)}$.

Other areas such as social and health subsequently began to use PPA methods, which also demonstrates this theoretical and methodological influence until the present day, in which the main focus is the analysis of a real situation experienced by a professional in their work, as happened in the "Balint groups". In this way, it should be clear that there is an articulation with the private dimension of the professional; it is authorized and encouraged, but never imposed. The PPA methods then deal with training rather than therapeutic work, using the active cooperation of all participants in the group ${ }^{(7)}$.

The other theoretical line that supports analysis of practices stems from the work of Donald Schön and Chris Argyris on the science of action. They assume that action is the source of knowledge, from which Schön developed the concept of the "reflective professional". He found that professional practice situations are marked by complexity, uncertainty, instability, particularity and value conflicts. For the author, the problems do not arrive pre-determined in the hands of the professional; they must know how to reconstruct the problem into a problem that they can solve. It is reflection in action, the way in which the professional reflects after the result of their action when seeing the produced results ${ }^{(6-7,14)}$.

The concept of reflexivity developed by the educator Donald Schön makes it possible to work on a variety of subjects found simultaneously in life or in professional practice, bringing together the sciences, techniques and arts to understand the complexity of the human condition, seeking to develop autonomy and awareness in the subjects and the community ${ }^{(14)}$.

Reflective practice enables professionals to critically deal with the determinants of the work process and to carry out their practices with autonomy and protagonism ${ }^{(15)}$. In this perspective, experience and action must be analyzed individually and collectively, so that group knowledge can be built and expressed, recognizing them as authentic knowledge sources ${ }^{(16)}$.

From these theoretical considerations it is possible to understand PPA as a training methodology that uses several techniques that produce knowledge and experiential knowledge (from reflecting on the action). In general, this training methodology has the following characteristics ${ }^{(17)}$ :

Final approach - a training method; aims at building professional identity and professionalism.

Group Approach - a group member exposes their practice and with the help of their peers tries to elucidate it or give a sense to itself, to their practice.

Follow-up approach - the facilitator (who is an expert) has the function of providing reading references and theoretical subsidies which enable understanding the analyzed situation, and not giving the solutions or formulas for the exposed problems.

Approach instrumented by knowledge and analysis tools the knowledge is apprehended in four dimensions: instrumental (formalize the practice); heuristics (open clues for reflection); problem-solving (helps to solve problems); and changes (allows the creation of new representations).

Approach and place of articulation practice-theory-practicealways begins by reporting experienced practices brought up by the group. The peers question and propose clues for analysis, the facilitator provides theoretical inputs and knowledge that serve as reading tools for understanding, but what matters is the group ideas.

Thus, the PPA is done by the group participants who work to co-construct the meaning they give to their practices and to improve professional techniques. This individual elaboration becomes a group work, which has a certain duration and requires the presence of a facilitator, usually a professional who dominates the analyzed practices, thus ensuring the subsidized methodology in the chosen theoretical framework ${ }^{(10)}$.

With regard to the facilitator, they can take different positions: driving, monitoring, regulation or training, their role is to ensure the structure of the method, the operating rules and the group safety. They must be able to listen, have experience in conducting groups and benefit from supervising ${ }^{(7,18)}$.

\section{DifFERENT TYPES OF PROFESSIONAL PRACTICE ANALYSIS METHODS}

There are different PPA methods in the literature, but what is common among them is the use of a work/placement situation as a starting point for student/professional reflection. The difference between these methods is due to their purpose and the theoretical approach in which they are anchored. The following will present some examples of methods found in the French literature ${ }^{(6-7,19)}$ :

Professional Development Group (PDG) - seeks to accompany people in pedagogical teams; allows the participants themselves to find their action strategies. It is a device that helps the narrator to make a decision through several 
propositions made by the group members, is a space to speak and develop listening that is anchored in the Rogerian movement (Carl Roger's non-directive theory, centered on the client), with a philosophical and humanistic approach to the relationship.

Balint orientation group - centralized in monitoring the person. The unconscious psychological articulations between the individual personality, singular and the professional personality will be worked on. It is a space where the individual does not only speak or express themselves, but above all, they can elaborate the questions that influence their personality, their unconscious, their professional practice, from a psychoanalytical orientation. However, it does not constitute a group of solutions or therapy.

Groupe Entraînement de Analyse de Situations Éducatives (GEASE) - is used in a group, seeks to develop analytical skills and acquire knowledge through repeating the act of analyzing various professional practice situations, seeking to make "knowledge that is hidden" explicit in the actions. It is a training tool aimed at transforming people, habits, groups, teams and institutions; it has a perspective of psycho-sociological or reflexive analysis and one of its central theoretical approaches is multi-referential.

The multireferential approach was initially developed by Jacques Ardoino, who recognized the complexity and heterogeneity that characterize social practices. This is the fundamental concept for understanding phenomena within the human sciences, especially educational phenomena. For this author, this approach must be built through joining and approaching several disciplines, which are part of a dialectical universe, in which thought and knowledge are conceived in constant movement, thereby enabling knowledge construction, which implies in a break with linear, unitary and reductionist thinking ${ }^{(20)}$.

In this perspective, the GEASE methodology is based on the multireferential approach so that the group can apprehend and understand situations in all their dimensions, enabling access to the various levels of analysis: pedagogical, institutional, sociological, and psychological, among others, which allows a diversified view of the experienced situations ${ }^{(21)}$.

As previously mentioned, the author's experience is based on the use of the GEASE professional practice analysis method, so that the focus of this theoretical reflection seeks to identify the possible contributions to training reflexive professionals in the Brazilian nursing context.

\section{THE GEASE METHOD: ITS ACRONYM AND OPERATING MODE}

GEASE is an PPA method that is used in a group, aiming to analyze complex professional situations in order to build a reflexive professional posture ${ }^{(3,5,22)}$.

The main purposes of this method are to: build, maintain and restore professional identity, since people are always caught up in the institutions and the tasks to be performed ${ }^{(3)}$. Institutional 'capture' of professionals most often occurs through routine, which is difficult to be broken, by rigid norms, crystallized behaviors, institution politics/interests, domination relations, authoritarian conduct, among other factors that contribute to producing unanalytical and mechanized professionals.

The facilitator needs to ensure three basic rules to conduct the GEASE method: confidentiality, non-judgment of values and the involvement of each participant in the performed work.

In conducting the GEASE method, the implication has a sense of involvement and commitment by all the participants in the group and by the facilitator in all development phases of the practical analysis sessions, the founding element of the existence of the group and its evolution. The GEASE mainly emphasizes the narrator's engagement, because if no situation is reported, it is not possible to propose an analysis work of the practice to the participants ${ }^{(19,22)}$. On the other hand, the involvement of each member to analyze the described situation enables an interactive dialogue between the participants, who bring with them their references and their behaviors, meaning their professional situations which serve as a resonance box, which "touches" the practice of each one from a collective reflection. Thus, the implication of the participants is a sine qua non condition for accomplishing the GEASE ${ }^{(22)}$.

The group dimension in the GEASE method is of fundamental importance, since this is a place of listening and protection for the reporter and the other participants. Thus, throughout the development of the practice analysis session, the facilitator needs to ensure the rules of confidentiality and non-judgment of values about the people involved and the events reported ${ }^{(3,22)}$. In this sense, the participants are not allowed to express preconceived ideas or opinions without knowledge, analysis or reflection on the experienced situation, constituting an indispensable condition for professionals to feel safe, protected and to make their statements as authentic as possible.

Thus, the use of GEASE in vocational training enables students/professionals to appropriate analysis skills by their own practice, at a time of strict confidentiality and outside of any value judgments that may lead to unfounded and unilateral discussions and analyzes ${ }^{(23)}$.

The meaning of the GEASE acronym ${ }^{(3)}$ :

\section{G (GROUPE) - Group}

GEASE is not a discussion group or to discuss a general problem, such as: where does the doctor's authority come from? Is there a good method for managing human relations?; among other broad and general issues, but it is used to discuss specific situations experienced at work. This method is also not an expression group for the therapeutic purpose of overcoming a trauma or combating addiction, such as Alcoholics Anonymous. It should be emphasized that even if there are times of exchange, arguments, a relationship of support and help, GEASE must be distinguished from therapeutic groups.

The GEASE device is then a training group to analyze work situations that are important in vocational training, supported by different knowledge (social sciences, politics, history, philosophy, among others). 


\section{E (ENTRAîNEMENT) - TRAINING/REPETITION}

The frequency and regularity of GEASE enable exercising, progressing, building and refining analytical skills. Ask yourself: Why is it necessary to "train"? Because they are mental attitudes and postures which are not spontaneous and which you have to discover and make sure of what you are going to say. It takes time and several sessions to attain these attitudes. It is necessary to multiply the tests, the errors and the corrections.

The session is a moment in which a parenthesis (i.e. it becomes hypothetical) is placed in the reported situation and one only seeks to understand, with the help of another's point of view and interpretations, without value judgment or advice to act, for example: "you could never have done it" or "you should have done it, thinking about your future", among others. It is because of these parentheses that the reported situation becomes suspended and serves as a support to train introducing questions and hypotheses and to analyze a situation, which is "suggested" to the group by the reporter.

Thus, the main purpose of this group work is neither therapeutic help nor to help the reporter to make a decision (if this happens as a secondary benefit, it is better), but if you train to analyze situations for the purpose of training, in order to modify certain spontaneous attitudes that we humans have, such as: the tendency to have a unilateral view of things and situations; to only seek an explanation; the inability to put oneself in the other's shoes; to be able to listen and to distance themselves from the situation. Which means if you train to have a reflexive posture that is open to the complexity of situations to better understand and act in the real present or future situations of professional life.

\section{A (ANALYSE) - ANALYZE}

After the reporter exposes a situation, the group intervenes to explore the situation and develop hypotheses which enable it to be interpreted. The reporter elaborates their speech from extracts of crude facts, imaginary representations and personal interpretations which give meaning to what they experienced. This account is already considered an analysis, which in some ways is still enigmatic for the reporter, but at the time of sharing they are forced to organize ideas beyond the transposition of language. This first time of the story, even before intervention by the group, often contributes so that the reporter can already see things in a different way.

In the phase of collecting complementary data, the group participants are encouraged to ask clarifying questions of the situation (to specify the scenario, to perceive those involved, their status, their relations, among others) and to bring some elements to light that have been omitted. This helps the reporter to pin down the details, to find the right words, to clarify the issues that were hidden in the "dark zone".

\section{S (Situation) - Situation}

The situation is a unique configuration in which the subjects of a reported situation act and react. It is a precise time of statements, specific place for exchanges. It can be said that the situations basically go through three stages: real; represented/reported/described; and elaborated/thought of from concepts.

\section{E (ÉDUCATIVE) - EdUCATIONAL}

GEASE can be used in several professionalization stages of individuals: in the initial training phase, contributing to construct the professional identity, as a tool that can help to give sense in articulating theory/practice. In continuing education, another training stage, in which it reinforces professional identity, allowing to analyze experiences in difficulties and suffering, often restoring self-esteem, which enables confronting experiential knowledge and theoretical references. At this training stage, this method can also become a place to start empowering people to lead the group, not just a place of situation analysis.

\section{Operating steps and evaluating GeASE}

In order to operationalize GEASE, the participants and the facilitator are arranged in a circle to facilitate dialogue between all of them in a group of 12 to 15 people, maximum. The facilitator presents the method, clearly showing its purpose, its operating rules and its development from the following stages, which are identical in all meetings ${ }^{(3,21-23)}$ :

Choosing the situation: each participant briefly reports a specific professional situation, while the others take note to then choose the one that will be analyzed. Approximate duration: 15 minutes.

Presentation of the situation: the reporter presents the situation to the group, without being interrupted by the other participants. At the end, they elaborate an issue that will guide reflective analysis. Approximate duration: 15 minutes.

Collection of complementary information: the other participants express their doubts about the context, the participants, the elements of the discourse and the obscure points of the situation. Comments, value judgments, interpretations and closed questions are not accepted. Approximate duration: 30 minutes.

Elaboration of hypotheses: the reporter withdraws from the group and does not participate in the discussion. With their back to the group with a sense of getting away from the situation, they should listen to the discussion without being able to react, but they are motivated to take note of the reflections by the group members, who are invited to formulate hypotheses by relying on what is known from the presented situation. Approximate duration: 45 minutes.

Summary of the reporter: the reporter returns to the group and expresses themself freely about what they have understood, without being interrupted by the other participants. They elaborate their interpretation of the situation based on the evaluation of the hypotheses formulated by the other participants. Approximate duration: 15 minutes.

Metacognitive phase: this is a synthesis of the observations and expressions, in which each member is invited to freely express their experience using the method, meaning their impressions, feelings, failures, positive and negative opinions, among others. Approximate duration: 30 minutes. 
In addition to the operation steps of this PPA method, it is also necessary to know the positives and concerns related to its use. Thus, the synthesis of an evaluation carried out by Nadine Faingold in France in 2003, based on the responses of facilitators who coordinated PPA sessions using $\mathrm{GEASE}^{(23)}$, is an important study to support the reflections of the authors of this theoretical article.

In her evaluation, the author stresses that even though the facilitator has to rigorously follow the GEASE steps, this is precisely what gives her certainty to know what the objectives are and where she wants to go with the PPA. The facilitators considered that the group participants learned to analyze the situations, since the discussions contributed to the reporter narrator finding their own answers. In addition, facilitators avoided value judgments that led to sterile and unfounded discussions, with a view to protecting the reporter's self-esteem. One of the most positive points was the quality of experience exchanges, the sincerity of the debates and the trust that was established during the PPA sessions. Participants progressively improved their listening quality and formulation of shared issues in the group ${ }^{(23)}$.

As concerns found in the evaluations in using GEASE, one can point out the difficulty of some students/professionals in sharing their problems, as there are those who do not want to take the floor to report a probationary/professional situation. In addition, the facilitators pointed out the difficulty of some participants in fulfilling requirements such as: frequent attendance and punctuality, among other factors, as well as the fact that certain students/professionals put themselves in the role of "mere consumers of training" in only seeking the answers, rather than problematizing complex situations ${ }^{(23)}$.

\section{Contributions AND transpositions of THE GEASE METHOD FOR REFLECTIVE TRAINING IN BRAZILIAN NURSING}

Considering the theoretical considerations, it is possible to point out some important contributions of GEASE to training reflective professionals in nursing, such as:

- being a method that starts from a specific situation and experienced by a student/professional, allowing it to take "a certain distance" from the reported situation. It should be emphasized that "taking distance" does not mean not forgetting the complexity of the situations from a systemic perspective, since it is necessary to take into account the context, those involved, the work done, the implications of the subjects and the organizational aspects.

- its steps, rules of operation and the role of the participants are made explicit from the first meeting in order to promote a safe environment for all. From the discourse of the reporter and the emotions experienced, the group members are encouraged to elaborate different interpretive hypotheses to transcend a whole unilateral view of the situation, aiming to develop analytical skills and certain mental postures, such as the ability to put oneself in the place of another, to actively listen, to not expose their value judgments in an unfounded way (no value judgment).
- the fact that the PPA sessions using the GEASE methodology are collective and limited to a moment in time, which aims at alternating between group meetings and returning to the organizations, enables students to reflect on the importance of teamwork, helping the reporter to modify their own representation of a situation and the other participants to get in touch with the various points of view.

- the PPA methods, in particular GEASE, are part of the curricula of the nursing schools in France as an official training method, in which the institutions recognize the necessity of this construction time of reflexive practice, which can be studied and applied by Brazilian schools.

These characteristics make it possible for this training method, which was initially used in the education field in France, to be reproduced in several professional areas, as well as in other realities such as undergraduate and continuing education in Brazilian nursing.

Thus, it is necessary to start from some questions to think about the transpositions to this reality:

- how to insert PPA methods, especially GEASE, into training nursing professionals, not as a discipline, but as a space for reflective training and the construction/ strengthening of professional identity?

- how to work with the issues of lifelong/continuing education, not from a "banking" perspective, but using methods such as GEASE which make it possible to analyze professional practice from situations experienced by professionals? The extension project that was cited in this article may be considered a first experimentation; however, it still needs to be studied, evaluated and further investigated.

Many other questions could be brought forward in this article, however we chose to intertwine some considerations into the next topic which are not conclusive, but in the sense of opening the way to continue the study and discussions about this method.

\section{FINAL CONSIDERATIONS}

The consulted literature and the experiences of the authors, especially those obtained from the extension project mentioned in this article, allow us to make some considerations, even if incipient, about the use of the GEASE methods in training Brazilian nursing professionals (undergraduate and continuing education).

It is considered that this is a method that offers the opportunity to open a space for reflective thinking by nursing professionals, since they are faced with a diversity of situations which are reported, questioned and analyzed in the PPA sessions, thereby enabling a collective construction of knowledge from recognizing the complexity of the work process and interpersonal relations.

In this collective space, both the participants and the facilitator have the possibility of self-criticism and elf-reflection, 
since everyone has the opportunity to learn, to listen, respect and accept (or not) the different points of view related to work/internship situations, which are elaborated through questioning and interpretive analyzes constructed by the group, and not from previous unilateral judgments.

In this perspective, the importance of teamwork and group potency becomes evident in the various organizational contexts. In the GEASE sessions, the participants serve as a "mirror" for each other at some moments, as the shared situations echo in the individual experiences, which can contribute to constructing a professional identity of critical and reflective nursing workers.

The authors of this theoretical article point out that there are research articles to reports of experiments on the use of
PPA methods in the French literature, including evaluating GEASE. However, the Brazilian reality is different, which may hinder the operationalization of these devices in their entirety. Therefore, they consider it necessary to know these methods even more, both from the theoretical perspective and practice, in order to understand the possibilities of adaptation/creation of its use in training reflective professionals in Brazilian nursing.

Thus, from this theoretical reflection it is suggested to carry out other studies and research focusing on PPA methods in order to provide a consolidation of theories and training methods that support nursing science, thus contributing to developing knowledge and the profession.

\section{RESUMO}

$\mathrm{Na}$ enfermagem, para que o trabalho não se torne mecanicista, a equipe necessita desenvolver um olhar crítico sobre seu saber, seu saberfazer e seu saber-ser. A formação de profissionais da enfermagem, pensada a partir de uma perspectiva crítica e reflexiva, motivou este estudo, que se pautou no referencial teórico e na experiência das autoras com a utilização do dispositivo de análise da prática profissional Groupe Entraînement de Analyse de Situations Éducatives. Esse dispositivo visa, em grupo, analisar situações profissionais com a presença de um facilitador. O objetivo é analisar as contribuições do Groupe Entraînement de Analyse de Situations Éducatives para a formação de profissionais reflexivos na enfermagem. As etapas, regras de funcionamento e o papel dos participantes são explicitados, a fim de promover um ambiente seguro para todos, permitindo aos membros do grupo a elaboração de hipóteses para compreender a situação e desenvolver competências de análise e reflexão. Conclui-se que o referido dispositivo oferece a oportunidade de abrir um espaço para o pensamento reflexivo, respeitando os diferentes papéis e tempos destinados à fala de cada participante, construindo a sua identidade profissional.

\section{DESCRITORES}

Enfermagem; Educação em Enfermagem; Educação Continuada em Enfermagem; Prática Profissional.

\section{RESUMEN}

En la enfermería, a fin de que el trabajo no se convierta en mecanicista, el equipo necesita desarrollar una mirada crítica sobre su saber, su saber-hacer y su saber-ser. La formación de profesionales enfermeros, pensada desde una perspectiva crítica y reflexiva, motivó este estudio, que se pautó en el marco de referencia teórico y en la experiencia de las autoras con la utilización del dispositivo de análisis de la práctica profesional Groupe Entraînement de Analyse de Situations Éducatives. Ese dispositivo tiene el fin de analizar en grupo situaciones profesionales con la presencia de un facilitador. El objetivo es analizar los aportes del Groupe Entraînement de Analyse de Situations Éducatives para la formación de profesionales reflexivos en la enfermería. Se enseñan las etapas, reglas de funcionamiento y el papel de los participantes, a fin de promover un entorno seguro para todos, permitiendo a los miembros del grupo la elaboración de hipótesis para comprender la situación y desarrollar competencias de análisis y reflexión. Se concluye que el mencionado dispositivo brinda la oportunidad de abrir un espacio para el pensamiento reflexivo, respetando los diferentes papeles y tiempos destinados al habla de cada participante, construyendo su identidad profesional.

\section{DESCRIPTORES}

Enfermería; Educación en Enfermería; Educación Continua en Enfermería; Práctica Profesional.

\section{REFERENCES}

1. Sari V, Beck CLC, Ressel LB, Silva RM, Sehnem GD, Tavares JP. De que corpo se fala no cotidiano da enfermagem. Cogitare Enferm [Internet]. 2009 [citado 2017 nov. 22];14(3):547-52. Disponível em: http://www.redalyc.org/pdf/4836/483648976020.pdf

2. Spagnol CA, Fernandes MS, Flório MCS, Barreto RASS, Sant'ana RPM, Carvalho VT. O método funcional na prática da enfermagem abordado através da dinâmica de grupo: relato de uma experiência. Rev Esc Enferm USP [Internet]. 2001 [citado 2017 nov. 22];35(2):122-9. Disponível em: http://www.scielo.br/pdf/reeusp/v35n2/v35n2a04.pdf

3. Fumat Y, Vincens C, Étienne R. Analyser les situations éducatives. Issy-les-Moulineaux: ESF; 2003.

4. Chocat J. Du référentiel de formation en soins infirmiers au dispositif d'analyse de pratiques professionnelles: quel parcours à explorer? Rev L'Analyse Pratiques Professionnelles [Internet]. 2013 [cited 2017 Nov 22];(1):14-33. Available from: http://www.analysedepratique. org/wp-content/uploads/jean-chocat-revue-app-sept2013.pdf

5. Mauduit S. Retour d'expérience de mise en place d'un dispositif APP en santé mentale destiné aux stagiaires infirmiers. Rev L'Analyse Pratiques Professionnelles [Internet]. 2017 [cited 2017 Nov 22];(10):64-71. Available from: http://www.analysedepratique.org/wp-content/ uploads/stephanie-mauduit-revue-app-mai2017.pdf

6. Monceau G. Entre pratique et institution. L'analyse institutionnelle des pratiques professionnelles. Nouvelle Rev L'Adaptation Scolarisation [Internet]. 2008 [cited 2017 Nov 22];1(41):145-59. Available from: http://www.cairn.info/revue-la-nouvelle-revue-de-l-adaptation-et-dela-scolarisation-2008-1-page-145.htm.

7. Lagadec AM. L'anlyse des pratiques professionnelles comme moyen de dévelopment des compétences: ancragem théorique, processus à l'ouvre et limites de ces dispositifs. Rev Rech Infirmiers [Internet]. 2009 [cited 2017 Nov 22];(97):4-22. Available from: http://fulltext. bdsp.ehesp.fr/Rsi/97/4.pdf 
8. Campagnoli M, Pezzato LM, Spagnol CA, Mourão LC, Garcia RA. Institutional analysis of the nursing practice: an experience at the health care center. Diversitates Int J [Internet]. 2017 [cited 2017 Nov 29];09(02):25-43. Available from: http://www.diversitates.uff.br/index. php/1 diversitates-uff1/article/view/188/112

9. Guillier D. L'analyse institutionnelle des pratiques professionnelles. In: Blanchard-Laville, C, Flabet D, organizadores. Travail social et analyse de pratiques professionnelles. Paris: L'Harmattan; 2003. p. 21-46.

10. Blanchard-Laville C, Flabet D. Sources théoriques et techiniques de I'analyse des pratiques professionnelles. Paris: L'Harmattan; 2001.

11. Balint M. O médico: seu paciente e a doença. Rio de Janeiro: Atheneu; 1988.

12. Brandt JA. Balint Group: their specificities and its potential for a clinic working relations. Rev SPAGESP [Internet]. 2009 [cited 2017 Nov 22];10(1):48-55. Available from: http://pepsic.bvsalud.org/pdf/rspagesp/v10n1/v10n1a07.pdf

13. Castro TF, Moraes PN, Iguti AM. Grupos Balint-Paidéia: uma proposta de ferramenta pedagógica para a supervisão prática no Programa Mais Médicos. Tempus Actas Saúde Coletiva [Internet]. 2015 [citado 2017 nov. 22];9(4):137-49. Disponível em: http://tempusactas.unb. br/index.php/tempus/article/view/1734/1478.

14. Schön DA. Educando o profissional reflexivo: um novo design para o ensino e a aprendizagem. Porto Alegre: Artmed; 2000.

15. Netto L, Silva KL, Rua MS. Prática reflexiva e formação profissional: aproximações teóricas no campo da saúde e enfermagem. Esc Anna Nery [Internet]. 2018 [citado 2018 jun. 04];22(1). Disponível em: http://www.scielo.br/pdf/ean/v22n1/pt_1414-8145-ean-2177-9465EAN-2017-0309.pdf

16. Galvani P. Etudier sa pratique: une autoformation existencielle par la recherche. Présences Revue D'étude Pratiques Psychosociales [Internet]. 2008 [cited 2017 Nov 22]1:1-11. Available from: https://www.uqar.ca/uqar/universite/a-propos-de-luqar/departements/ psychosociologie_et_travail_social/n1galvani.pdf

17. Altet M. L'analyse de pratiques: une démarche de formation professionalisante? Rech Formation [Internet]. 2000 [cited 2017 Nov 22];35(1):25-41. Available from: http://www.persee.fr/docAsPDF/refor_0988-1824_2000_num_35_1_1668.pdf

18. Faingold N. Un dispositif d'analyse de pratiques centré sur la question que se pose le narrateur. Rev L'Analyse Pratiques Professionnelles [Internet]. 2014 [cited 2017 Nov 22];(3):3-12. Available from: http://www.analysedepratique.org/wp-content/uploads/nadine-fainfoldrevue-app-juin2014.pdf

19. Académie de Reims. Groupe de Formation et de Recherche (GFR). Analyse de pratiques professionnelles (APP) : 2002-2004. Rapport final [Internet]. Reims (FR): Université de Reims; 2005 [cited 2017 Nov 22]. Available from: http://www.univ-reims.fr/gallery_files/site/1/90/4401/5803/5807/5809.pdf

20. Martins JB. Contribuições epistemológicas da abordagem multirreferencial para compreensão dos fenômenos educacionais. Rev Bras Educ [Internet]. 2004 [citado 2018 jun. 04];26(2):85-182. Disponível em: http://www.scielo.br/pdf/rbedu/n26/n26a06.pdf

21. Laieb G. Apprendre à " geaser »: Le gease, une méthodologie pour appréhender l'analyse de situations éducatives complexes. Cahiers Dynamiques [Internet]. 2010 [cited 2018 June 04];3(48):78-83. Available from: https://www.cairn.info/revue-les-cahiers-dynamiques2010-3-page-78.htm

22. Lamy M. Propos sur le G.E.A.S.E. Expliciter J L'Association GREX [Internet]. 2002 [cited 2017 Nov 22];(43):1-13. Available from: https:// www.grex2.com/assets/files/expliciter/43_janvier_2002.pdf

23. Faingold N. Formation de formateurs à l'analyse des pratiques. Rech Formation [Internet]. 2006 [cited 2018 June 04];51:89-104. Available from: http://journals.openedition.org/rechercheformation/495 